\title{
FRA KUNSTKAMMER TIL MODERNE MUSEUM
}

Peter Wagner

Ved kongelig resolution af 31 . marts 1759 oprettedes naturalie-kabinettet på Charlottenborg. Det var en af kongens private midler understøttet institution, hvis opgave var, at indsamle viden om og undervise lage og larde $i$ zoologi, mineralogi, bjergvarksdrift og oeconomie. Til Kabinettet eller Amphitheatret, som det hed i de forste udkast til fundats, var knyttet to professorer, der under ansvar overfor overdirektøren, overhofmarskal A.G. Moltke, skulle bestride forskningen og undervisningen, der skulle foregå på modersmålet og rettes mod såvel akademikere som ularde. Til kabinettet knyttedes forskellige samlinger af mineralogisk og zoologisk karakter, men ogsa botanikken var, omend $i$ beskedent omfang, representeret.

Kabinettet var en udvidelse af et projekt påbegyndt i 1752, da kongen under 3 . oktober havde besluttet oprettelsen af de botaniske anstalter på Amalienborg, der som mål havde at indsamle oplysninger om indenlandske planter og deres rette brug, og igen gøre oplysningerne tilgængelige for kongens undersåtter, såvel lærde som ulærde. Endvidere skulle professor botanices anstille forsøg, i samarbejde med interesserede forst- og landmænd, med udenlandske planter af økonomisk (d.v.s. landbrugsmæssig, forstmæssig eller medicinsk) interesse og eventuelt opformere disse til uddeling, hvis de med udbytte kunne dyrkes i landet. Da den berømte Linnæus havde fået disse planer forelagt, havde han ment, at man ikke isoleret kunne studere eet af naturens tre riger, og havde foreslået, at zoologi og mineralogi blev inddraget i planerne. Derfor var naturaliekabinettet blevet oprettet og den ene af de to professorer, Jørgen Tyge Holm (172659), var elev af Linnæus. Den anden, den norskfødte læge Peder Ascanius (17231803), havde på rejser med kongelig understøttelse i Europa uddannet sig til mineralog og zoolog, bl. a. hos Linnæus. ${ }^{1}$

De til institutionen knyttede samlinger fremkom dels ved, at såvel Ascanius som Holm overdrog deres til kabinettet. Endvidere overførtes den samling jordprøver, som kongelig mineralinspektør Andreas Birch havde opbygget på sine rejser i Danmark på jagt efter porcelænsjord og skænket kongen, til kabinettet. ${ }^{2}$

Det var naturligvis ønskeligt at udvide samlingen så meget som muligt, og den 26. maj 1759 foreslår Ascanius i et brev til Moltke, at "Samlingen paa Konstkam- 
22 meret maatte enten heel eller til deels komme os til Hielp, thi P. Holms og min samling vil ei være tilstrækkelig at læse over. Var det ikke bedre at have en complet samling end 2 ufuldstændige. $x^{3}$ Ved «samling» må Ascanius forstå Producta naturalia eller den del af Kunstkammeret, der omfattedes af Naturaliekammeret.

Det kunne synes anmassende at ville forgribe sig på den kongelige samling, men faktisk havde kongen selv i fundatsen givet bolden op ved at opfordre alle til at komme med interessante naturalier eller modeller af maskiner og lignende. Samlingen skulle omfatte

alle Slags saavel fremmede som især Vores egne Rigers og Landes Naturalier og Produkter, dog fornemmeligst de, som har nogen Indflydelse i Bergog Landhusholdningen, saasom Mineralier af allehaande Erts-, Jord-, Sten-, Ler-, Salt- og Svovlarter, Fossilier, Petrifikater, Konkylier, Koraller, Polyparier og Havvækster m.m. Videre Herbaria viva eller indlagte Urter, Dyr, Fugle, Fiske, Amfibier, Orme, opstoppede eller i Brændevin forvarede Insekter, o.s.v. Ligeledes skal her også forvares Rudimaterier, Prøver af alle Slags Manufakturer og Handelsvarer, Farve- og Træarter, saavelsom og Modeller af adskillige slags Machiner, brugelige ved Bergbygning, Agerdyrknings og den øvrige Landhusholdnings-Redskaber, Fiskeriets m.m. ${ }^{4}$

Endvidere skulle professorerne på deres embedsrejser skaffe objekter til samlingen, og Holm anmoder da også om på sin udenlandsrejse, som han skulle tiltræde i september, at få 200-300 rdr. til

at bestride de nødvendige Udgifter ved Modellers eller Teigningers Anskaffelse af oeconomiske Machiner og Instrumenter, forekommende naturaliers Indkiøb...5
Se, det lyder jo som et gammeldags naturaliekabinet. Det fremgår af Chatol- og Partikulærkassens regnskabsbilag 1759-70, at der faktisk blev ofret ret mange penge på indkøb af genstande til samlingen, men Ascanius var som sagt ude efter Kunstkammeret. Allerede 17. Marts 1759 havde han skrevet til Moltke:

Ethvert Hoff har nu fast sig et eget NaturalieCabinet adskildt fra de saa kaldede Gallerier, hvilket vores Kunstkammer egentlig er ${ }^{6}$

Som nævnt ovenfor foreslog Ascanius, at Kunstkammeret skulle afgive genstande fra Naturaliekammeret. Hvorledes det så end ved den lejlighed blev optaget, blev intet overført, men samlingerne blev reviderede. Bente Gundestrup oplyser, at mellem 1765 og 1775 nummereredes alle genstande, og heri var professoren ved Amalienborg-anstalterne, Georg Christian Oeder, og Peder Ascanius involverede. Oeder havde faktisk allerede i 1752 foreslået en revision ${ }^{8}$, men først i 1767 var det for producta naturalia's vekommende kommet dertil, at man kun manglede at forsyne genstandene med etiketter. I sin årsberetning over Naturaliekabinettet's virksomhed for 1767, hvori denne oplysning findes, afleverer Ascanius følgende salut:

Videre refererer mig til mine forhen ytrede tanker om det kammer, som i det Kongl Kunstkammer fører navn af Naturalier, nemlig: At, da bemælte er et Magazin, hvorudi en Mængde slette og uduelige ting, som ei offentlig burde være tilsyne, skiule de faa gode, disse da til nytte for Kongen og Ordens Skyld, med de Charlotenborgske anstalter burde forenes, hvorved og Kunst-sagerne, som med rette høre til det første sted, ville vinde det nu manglende Rom.? 


\section{TO MODSATRETTEDE OPFATTELSER}

Denne beretning må Moltke have forelagt kunstkammerforvalter Gerhard Morell (1710-71, forvalter fra 1765), som svarede Moltke $^{10}$, at han ikke kunne forstå, at Ascanius havde fået den idé, at noget kunne flyttes fra Kunstkammeret, Ascanius måtte da vide, at intet kunne fjernes herfra, førend at inventariet var færdigt, og alt behørigt nummereret; da kunne man se, om noget blev til overs, men det mente Morell nu ikke, at der blev, naar man skulle opretholde en samling, der i et århundrede havde hævdet sit ry, var blevet beundret af fremmede, og som landets børn havde holdt i ære som deres eneste seværdige skat. Han mente, at Verden og undersåtterne ville blive bestyrtede, hvis denne skat, der havde bestået siden Frederik III, blev slået i stumper og stykker,

Thi netop dette (Kunst) Kammer, som Ascanius $ø$ nsker at plyndre, er noget som det er meget svært at røre ved, uden at anrette en beklagelig ødelæggelse. Thi dels findes der i dets indretning en vis harmoni, der, selvom den ikke netop er efter tidens smag, så dog viser dets opståen. [...] Endnu mindre kan et helt led (nemlig Producta naturalia) undværes, uden at afhugge en sund krop arme eller ben; og sluttelig vil sager, der på deres plads endnu ser godt ud (men er) gennemhullede af tiiden falde i stykker, hvad der i den toårige undersøgelse har voldt mig bekymring nok, og der vil derefter enten ikke være noget tilbage i Kunstkammeret, eller Ascanius vil kun have tiloversblevne elendige tegn på krigsbytte fra Kunstkammeret. Ulykkeligvis vil en plyndring af Kunstkammeret ikke kunne skjules, da Lorenzen ${ }^{11}$ i folio har beskrevet indholdet i det prægtige Museum Regium og stukket det meste i kobber.
Her er to vidt forskellige opfattelser konvar moderne og Morell gammeldags; sidstnævnte havde jo netop, efter hvad man kan læse i dansk biografisk leksikon, ved kloge køb forøget og nyophængt billedsamlingen $i$ et moderne galleri, som Ascanius henviser til. Svaret på uoverensstemmelsen kan formentlig kun findes ved at gå tilbage i historien og se, hvorledes kunstkamre og naturaliekabinetter har udviklet sig.

Mogens Bencard har i Nordisk Museologi 1993:1 gennemgået kunstkammerets historie, så jeg skal gøre det så kort som muligt og fortrinsvis nævne de aspekter, som Bencard ikke gjorde så meget af.

\section{DE FØRSTE \\ NATURALIEKABINETTER}

De første naturaliekabinetter synes at være opståede i Italien hos de lærde, som havde brug for dem. De klassiske naturvidenskabelige forfatterskaber blev i renaissancen ikke længere ansete for komplette bl. a. på grund af de indtil da ukendte dyr, planter og produkter, der kom fra de nye verdener i øst og vest. Den lærdes bibliothek måtte derfor suppleres med disse nye objekter. Som følge heraf udvides bibliotheket med naturalia, og urtehavens køkken- og lægeurter suppleres med planter af alle slags fra alle Verdens dele, så naturaliekabinettet og dets udendørs afdeling, den botaniske have, opstår. Ejendommeligt nok er de botaniske haver fra begyndelsen ikke kun private, men også institutionaliserede; de to ældste kendte botaniske haver (ikke urtehaver) opstår samtidig i Pisa og Padua 1543.

Naturaliesamlingerne var derimod i begyndelsen private. Calceolari og Fer- 
PETER WAGNER

24 rante Imperato var begge apothekere, der anlagde store samlinger af naturalier, Ulysse Aldrovandi (1522-1605) var professor ved Bologna's universitet, og har uden al tvivl benyttet sin samling til såvel forskning som undervisning. Det fremgår af hans publikationer ${ }^{12}$ og af, at han indrettede nogle rum til studium og sammenligning. Aldrovandi demonstrerer her en udvikling,; som får meget stor betydning for naturvidenskabens udvikling, som faktisk begyndte i apothekernes samlinger, nemlig indførelsen af den komparative methode; i samlingerne og deres beskrivelse holdt mange sig ellers længe til den rent deskriptive. Mange andre privatkabinetter opstår, hvoraf nogle - fortrinsvis de af videnskabsmænd opbyggede benyttes til forskning og undervisning, $f$. eks. Ole Worms. Andre indeholder, eller består næsten udelukkende af, exotica eller monstrøsiteter, som af den grund betragtes som interessante. Det har fàet adskillige lærdoms- og navnlig kunsthistorikere til at mene, at opbygningen af naturaliekabinetter er et udslag af manierisme, hvad der i nogle tilfælde formentlig godt kan være rigtigt. I slutningen af det 16 . århundrede knyttes naturaliekabinetter og wunderkammere til de botaniske haver i Pisa (1590) og i Leyden, hvor der var menageri, men også enkelte artificialia. En større samling skeletter udstilledes i det anatomiske theater sammesteds, når der ikke var dissektioner i 1591, en idé Thomas Bartholin tog op i København. Senere udbyggedes samlingen ca. 1620 til et egentligt Wunderkammer med navnlig Aegyptiaca. I England knyttes samlinger til Kollegierne, til bibliothekerne og til anatomiskolerne, selv East Asiatick Company får en samling. Disse samlinger var ikke udelukkende naturalia, de indeholdt også mønter og ethnographica. I disse samlinger kan man betvivle berettigelsen af betegnelsen naturaliekabinet, englænderne foretrækker også selv at kalde dem Cabinets of Curiosities.

Den oprindelige opfattelse af Naturaliekabinettet som en udvidelse af biblioteket fastholdtes af Claude de Molinet (162087) ved bygningen af et nyt bibliothek ved klosteret Ste Genevieve i Paris, hvor han hævdede at bibliotheket skulle forsynes med «et kabinet med sjældne og mærkværdige genstande, som skal have tilknytning til lærdom og tjene videnskaben». ${ }^{13}$

De mere eller mindre offentlig tilgængelige samlinger, der er knyttede til laug og universiteter, danner, ligesom de private samlinger, der senere indgår $\mathrm{i}$ offentlige samlinger som f. eks. Hans Sloane's, en slags overgang til egentlige kunstkamre, der alene af økonomiske grunde nærmest må betegnes som en fyrstespecialitet.

Kunstkammeret eller Wunderkammeret opstår omtrent samtidig med naturaliekabinettet og findes primært $\mathrm{i}$ to former: som studiolo og som kunstkammer.

Studiolo, der går tilbage til 14-hundredetallets sidste halvdel, er et privat studerekammer, eller kabinet, i hvilket makrokosmos er repræsenteret i mikrokosmos; hvor de forskelligste naturalia og artificialia og scientifica, historie og kunst er repræsenteret; til hvilket fyrsten kan trække sig tilbage og hvile eller studere. Paradigmet på den lærde fyrste (som havde et bevaret studiolo) må være Federigo da Montefeltro (1422-82), hertug af Urbino. Genstandene i en sådan fyrstes private museum har, udover at repræsentere sig selv, en symbolsk funktion som tegn for deres slags (genus) i makrokosmos, en 
funktion genstandene $i$ et naturaliekabinet sædvanligvis ikke har (måske undtaget afbildninger af de desiderata, som ikke findes in natura i kabinettet, og de dele af planter og dyr, der som partes pro toto træder i stedet for den fuldstæendige organisme).

Antog en fyrstelig samling større dimensioner, kaldtes den et kunstkammer. Når universum - eller makrokosmos - skulle være repræsenteret, omfattede det ikke blot naturalia, men også menneskelige frembringelser, både ved hånden og ved ånden, d.v.s. at kunst i form af malerier, tegninger, stik, skulpturer, mønter og medailler skulle indgå ligesom maskiner, mikroskoper, modeller, redskaber og musikinstrumenter. Bøger (bibliotheker) og botaniske haver hørte principielt også med; nogle inkluderede også genealogiske tavler og våben etc. Det var ingen tilfældighed, at kunstkammerbygningen i København havde våben i stuen, bibliothek på første sal og kunstkammer på anden. I Hertug Leopold's museum i Ambrass udgjorde rustkammer og kunstkammer også en helhed.

\section{MIKROKOSMOS}

Museumstheoretikere opstod, men dem vil jeg forbigå, Mogens Bencard omtalte nogle af de vigtigste. Een vil jeg dog nævne. Den mest præcise beskrivelse af idéen om det altomfattende kunstkammer, Museum, Amphitheater, Theatrum mundi, findes hos Francis Bacon i hans Gesta grayorum fra 1594. I Mogens Bencards oversættelse lyder den:

Først skal man samle et fuldendt og fuldstændigt bibliothek, med alt, hvad mennesket $i$ sin snilde har skrevet. Dernæst en stor og vidunderlig have, med alle planter, der gror under forskellige klimatiske forhold og i forskellig jord. Derudenom skal bygges rum til alle sjældne dyr og fugle, og to nærliggende søer, den ene med salt- den anden med ferskvand for en lignende variation af fisk. $O g$ således har man i lille skala en model af hele naturen. Det tredie skal være et passende stort kabinet, der skal rumme alt, hvad menneskets hånd har skabt ved udsøgt kunst eller maskine. Alt enestående, skabt ved tilfældigheder eller tingenes sammenblanding, og alt, som ved naturens luner er gjort livagtigt. Det fjerde skal være et tankens stille sted, således udstyret med maskiner, instrumenter, ovne og beholdere, at det kan være et palads, hvor man kan finde de vises sten. ${ }^{14}$

Man bemærker, at Bacon endog har fået de kuriositeter med, som i nogle kunstkamre, ligesom exotica, våben eller redskaber, alt efter ejerens personlige interesser, kunne forrykke eller helt udslette kunstkammerets funktion som mikrokosmos. Det bør nævnes, at mange botaniske haver også havde menageri og at forsøgene på at dyrke alverdens planter på eet sted, førte til opfindelsen af i dag så velkendte indretninger som læmure, læplantninger, mistbænke, orangerier og drivhuse med og uden opvarmning.

Billedet af det ideale museum eller kunstkammer sløres i nogen grad af den omstændighed, at de, ligesom haverne, hurtigt blev, eller måske fra begyndelsen var, statussymboler. (Jeg har, trods megen stor personlig respekt, mistanke selv til Federigo da Montefeltro). Ganske som de venetianske og hollandske købmænd ved import af sjældne planter fra deres handelspladser og kolonier demonstrerede deres forbindelsers betydning og dermed deres status, kunde fyrstens wunderkammer vise hans forbindelser, magt og kultu- 
PETER Wagner

26 relle stade (eller måske mere ondskabsfuldt formuleret, selviscenesættelse). DaCosta Kaufmann mener f. eks. at Rudolf II's berømte

kunstkammer i Prag havde betydning i diplomatiet, som blev understreget af dets fornemme præsentation [...] vi må se Rudolf's besiddelse af Verden i mikrokosmos $\mathrm{i}$ hans kunstkammer som et udtryk for hans symbolske beherskelse af den større Verden. ${ }^{15}$

Denne repræsentative side førte i det følgende 17. og 18. århundrede til, at det blev let at glemme sammenhængen mellem den lærde fyrste (eller den lærde købmand, mercator sapiens) og hans kunstkammer som refleks af hans interesser og lærdom. Derfor glemmes det ofte også i dag, at idéen om kunstkammeret som verdenstheater er tæt sammenknyttet med idéen om lærdom og om den lærdes funktion og evner, som den var $\mathrm{i}$ den første tid af institutionens levetid, uanset om den lærde var professionel lærd, købmand eller fyrste.

I renaissancen havde man bevaret middelalderens forestilling om, at den lærde beherskede al viden. Studium triviale og quadrivium gjorde studenten bekendt med alt i artium og de tre øvrige fakulteter jura, medicin og theologi klarede resten. Derfor svarede den lærde og hans studerekammer eller museum (ordet betyder: et sted, hvor videnskaberne dyrkes ${ }^{16}$ ) til hinanden, og derfor giver ordet universitas (vel nærmest: det altomfattende, nemlig de fire fakulteter) mening, som navn på den institution, hvor erkendelse lærtes og dyrkedes. Når den færdiguddannede beherskede al viden, var han principielt i stand til at beklæde alle stillinger i såvel den lærde verden, som i den profane. Derfor kunne professorer avancere fra den ene lærestol til den anden, på tværs af fakulteterne, og derfor var der intet besynderligt $\mathrm{i}$, at theologer studerede naturvidenskab, medicinere fysik (eller kemi) og jurister theologi og iøvrigt indgik i administrationen af kongeriger og fyrstendømmer. Det er også forklaringen på, at fyrsten skulle være lærd i det 15. og 16. århundrede. Man forventede $\mathrm{i}$ theorien, at han var kvalificeret til sit embede. (Dette princip er efter indførelsen af det repræsentative demokrati blevet forladt i statsadministrationen.)

Denne universelle lærdom var også dannelsesideal for dem, som ikke havde lærdom som levevej. Adelsmænd og købmandssønner studerede også. De tog ikke nødvendigvis eksamen, men for de fleste adelsmænd var en rejse til udenlandske universiteter en nødvendig forudsætning for en civil karriere som fyrstetjener. Lærde købmænd (mercatores sapientes) var ikke usædvanelige, for nogle af dem var det en nødvendighed i deres forretning at være om ikke lærd, så et stykke derhen ad. For ikke at nævne, at mange jurister og læger rekrutteredes fra deres stand. Det var disse grupper der, foruden fyrsterne, gæstede kunstkamrene.

Forudsætningen for at være med i det lærde lag var fuldstændig beherskelse af latin. Det var det sprog, al viden blev videregivet på, såvel skriftlig som mundtlig. Det var også diplomatiets sprog. Alternativt var alle, der ikke beherskede det, lukket ude. I den forstand var den lærde republik lukket.

\section{NYT LARDOMSIDEAL}

Dette lærdomsideal blev i løbet af sidste halvdel af det 17. århundrede og begyn- 
delsen af det 18. brudt ned. Spidsfindigt kan man måske påstå, at idealet om een fælleseuropæisk totalviden fik sit første grundskud ved reformationen i 1520'erne (siden Thomas Aquinas havde videnskabelig erkendelse været uløselig forbundet med forestillingen om Gud), noget mindre af en fuldtræffer den tysk-romerske kejsers afkald i 1556 på at være fyrsternes fyrste i Europa. Under alle omstændigheder besluttede franskmændene, at der skulle forandring til. Da Académie des Sciences grundlagdes i 1666 som en forskningsinstitution uden forbindelse til universiteterne, var det som en del af den kongelige propaganda. Académie Royale des sciènces var - sammen med de øvrige akademier - en demonstration af fransk kulturel overlegenhed. Dets møder og næsten alle dets publikationer var på fransk. Ved at fastholde fransk som samtalesprog tvang man de korresponderende (udenlandske) medlemmer til også at benytte dette sprog. ${ }^{17}$ Académie francaise havde samme forretningsgang. Hensigten blev tydeliggjort med de to opgaver, de to organer påtog sig: udgivelse af en lærebog i botanik for ulærde (på fransk) og en fransk grammatik og ordbog. Videnskabelig erkendelse skulle være almen tilgængelig, lærdomsmonopolet skulle brydes. I Tyskland foreslog juristen Christian Thomasius i 1687 en plan for udvikling af tysk til et sprog, der var brugeligt til videnskabelige formål (til stor forargelse for en del af hans kolleger). ${ }^{18}$ Det kan være grunden til, at A.H. Francke, der skulle blive en af pietismens største foregangsmænd, fra 1689 holdt en del af sine theologiske forelæsninger på tysk. ${ }^{19}$ Efter grundlæggelsen af universitetet i Halle 1694 udgår herfra pietisternes bestræbel- ser på, at opdragelse/uddannelse skal være så god så mulig og udstrækkes til alle i og udenfor de lærdes kreds; disse bestræbelser favoriserer automatisk brug af modersmålet, en udvikling, der navnlig bliver tydelig, da man ønskede de nye realfag (der jo ikke havde deres rødder i den antikke verden) indført til gavn for erhvervslivet, d.v.s. for ulærde.

Den enevældige stats administration, hvis mål er at gribe ind på langt flere områder end middelalderens og renaissancetidens stater havde mulighed for, stiller krav til sine embedsmænd, som den klassiske universitetsuddannelse ikke kan honorere, og ridderakademier med specialuddannelse for fyrstetjenere, og med undervisning på og $\mathrm{i}$ andre sprog end latin, bidrager fra det 17. århundredes slutning yderligere til at nedbryde det latinsprogede universitets videns- og uddannelsesmonopol og til at opbygge en embedsstand med en selvstændig identitet. ${ }^{20}$

Også den enorme forøgelse af mængden af viden, der finder sted fra ca. 1600 indenfor naturvidenskaberne, medicinen og fra ca. 1700 de økonomiske videnskaber, gør deres til, at renaissancens lærdomsideal åbenlyst bliver en fiktion. Man kan også sige det sådan, at den tid, hvor professorerne ascenderede ad senium, altså avancerede fra en lærestol til den næste, oftest begyndende som professor eloquentiæ og endende som professor theologiæ, der regnedes for det fineste (hvorfor selv en berømt naturvidenskabelig og medicinsk forsker som Thomas Bartholin endte som professor theologiae), eller hvor en international berømt videnskabsmand som Ole Rømer kom hjem til sit fødeland for at blive politimester, var forbi.

Den lærde adelsmand, den lærde køb- 
28 mand forblev heller ikke, hvad de havde været. Latin var ikke længere ubetinget nødvendig som internationalt dannet sprog. Fransk, tysk og italiensk kunne gøre det. Ophold ved universiteter (uden eksaminer) fortsætter nok, men bestemte, moderne, det vil i denne forbindelse også sige nye, universiteter med f. eks, økonomisk-statsvidenskabelige lærestole foretrækkes. Men frem for alt er tidsskrifterne kommet til. Også her var Frankrig først med Journal des scavans (1665), men senere, da Spectator, Mercure de France, Hamburgisches Magazin og hvad de nu hed, med deres aktuelle og efter datidens målestok rimelig let fordøjelige gengivelse af den videnskabelige og økonomiske litteratur og diskussion, let holdt den mondæne verden (og vistnok også den lærde) à jour, er man fra at være lærd gået over til at være dannet og oplyst. Denne udvikling krones med udgivelsen af Encyclopedien, der jo nok var skrevet af lærde, endda meget lærde, men for dannede mennesker. Ved sin opbygning, altså ordning af emner efter alfabetet, og ved at mange forfattere var nødvendige, er dette værk an sich et tegn på, at renaissancens lærdomsideal var opgivet. ${ }^{21}$

En samling som naturaliekabinettet på Charlottenborg blev altså oprettet med henblik på et helt andet publikum, end det kunstkamrene i deres oprindelige form var skabt for. Det var en udadvendt institution, med en specialsamling, der til brug for det interesserede publikum Liebhabere kaldet - naturligvis skulle være komplet, så alt nødvendigt kunne vises, forklares og bruges som eksempel. For den moderne Ascanius er Kunstkammeret, hvis lærde bruger er et fjernt billede om overhovedet til stede $\mathrm{i}$ hans verden, en uhensigtsmæssig sammenhobning af ting, der bedst kan studeres, hvis de kan ses ordentligt, hver for sig. Han ønsker derfor naturalia ført sammen med andre naturalier, hvor de samlet kan benyttes til undervisning. Samlingens chef, Morell, argumenterer derimod fuldkommen korrekt, med henvisning til den oprindelige mening med kammeret, hvor det væsentlige er, at naturaliekammeret sammen med de øvrige kamre, Antikvitetskammeret, det indianske kammer, artificialkammeret, heltekammeret og møntkabinettet, for ikke at nævne billedgalleriet, som han selv havde udvidet, udgør en helhed. Sammenhængen med bibliotheket og våbensalen nedenunder synes han derimod ikke at være kendt med. Så selv om Morell nok har en fornemmelse for universitas i samlingen, er hans opfattelse noget indskrænket i forhold til den oprindelige.

De objekter, der indgik i Charlottenborg-samlingen, var ikke meget forskellige, om overhovedet, fra, hvad der kunde findes i naturaliekammeret $\mathrm{i}$ et kunstkammer. Den udvikling, der på denne tid begynder, nemlig at kunstkamrene afløses af specialmuseer, er måske ikke så voldsom, som den kunne synes. Faktisk svarer en del af de nye museer (British Museum åbner 1759) jo ganske godt til de enkelte afdelinger $\mathrm{i}$ kunstkamrene. Denne nye udvikling kunne måske begrundes $\mathrm{i}$, at samlingernes størrelse, og den viden, der var nødvendig for at kunne lede, ordne og udbygge dem rigtigt, nu var så stor, at en enkeltperson ikke kunne spænde over den. Det kan da også være en forklaring. Personlig tror jeg dog, at den største ændring er, at de nye museer, principielt i hvert fald, også er udadvendte mod den dannede offentlighed, ikke længere gådefulde templer, der kræver nøgler i form af 
stor lærdom, for at kunne besøges med udbytte. At det så ikke straks altid lykkedes at arrangere udstillingerne, så de blev rimelig let tilgængelige er en ganske anden historie. Denne nye funktion ændrer intet ved at samlingerne fortsat er nødvendige til studieformål.

Tanken om sammenhæng og enhed blev dog ikke glemt. Christian Jürgensen Thomsen fastholdt jo, at museerne udgjorde en helhed, som Jørgen Jensen omhyggeligt har påvist i sin bog om Thomsens Museum.

Endvidere kan man glæde sig over, at man netop $i$ et værk som den franske encyclopedi forsøgte at fastholde idealet om en samlet opfattelse af al viden. At den ikke mere kunne rummes $i$ et hovede fremgår af, at der var mange forfattere ved værket, som dog netop ved en omhyggelig redaktion kom til at fremtræde som en helhed.

\section{SUMMARY}

\section{From Kunstkammer to Museum}

In 1759 the Natural Cabinet at Charlottenborg was established as an extension of the Royal Botanical Institute at Amalienborg founded in 1752. Both institutions were planned as places of research and teaching for the learned as well as for laymen. The disciplines studied and taught were botany, agriculture, forestry, gardening, zoology, mineralogy, mining and economy.

When establishing the collections necessary for the purpose, one of the professors at the Cabinet, Peder Ascanius, suggested parts of the collection of the natural chamber of the Royal Kunstkammer be transferred to the Cabinet, because one complete collection was preferrable to two incomplete ones. The custodian of the Kunstkammer, Gerhard Morell, protested against this, pointing to the fact that the Kunstkammer collection was a unit, no part of which could be removed without damaging the concept of the Kunstkammer.

This difference in view is based on the history of the concept of the Natural Cabinet and of the the Kunstkammer.

Both types of institution came into being during the Renaissance, the Natural Cabinet as a supplement to the library, as the then unknown organisms and natural products came from the new worlds in east and west and appeared not to be described by the classical authors. The Kunstkammer was designed as a microcosm representing the macrocosm just as the four faculties constituted universities in learned society. The botanical garden was seen as the outdoor part of the natural cabinet or Kunstkammer. The learned person, who had passed through the four faculties, had mastered all learning represented in the Kunstkammer. He also expected to be able to fulfill any official position in society. Access to the world of learning demanded an absolute command of Latin as this was the language in which all knowledge was made known in speech or writing.

In the last part of the 17th and the first part of the 18 th century the unity of language, learning and Kunstkammer was destroyed. In France and Germany scientific information was conveyed in lectures and published in the mother tongue, and institutions of research and teaching unconnected with the universities were established. The developing centralized state demanded from civil servants administrative skills that were not taught in the universities and Ritterakademien were founded to meet this need. The pietistic scheme of carefully educating all members of society advanced the idea of teaching laymen the results of scientific research to make them useful to society.

The foundation of the Royal Botanical Institute and of the Natural Cabinet was a result of this development, and the desire to create a complete collection of specimens for educational purposes as advanced by Ascanius, a logical consequence of this. The refusal of the request by Morell was correctly based on the concept of the Kunstkammer as a uni- 
30 ty reflecting a unit of the world and the knowledge about it, a unity, however, which by the 1760s had become a ghost of the past.

\section{NOTER}

1. Wagner, Peter: Det kongelige værk Flora Danica. i: Ole Villumsen Krog: Flora Danica og det danske hof. København 1990. p. 21 og 26.

2. Garbo, Axel: Geologiens Historie i Danmark. I. Fra Myte til Videnskab. København 1959. p. 126. Pro memoria fra Ascanius til Molkke, udateret, men med henvisning til pro memoria fra Holm, ligeledes udateret, men er skrevet efter 31. marts 1759.

3. I Bregentved Arkiv.

4. Fundation for Den Kongelige Danske Charlottenborgske Natural-HuusholdningsSamling. Kiøbenhavn 31. Martii 1759.

5. P.M. fra Holm til Moltke 22. May 1759. i Bregentved Arkiv.

6. I Bregentved Arkiv.

7. Gundestrup, Bente: From the Royal Kunstkammer to the modern Museums of Copenhagen. in: Oliver Impey and Arthur McGregor: The Origins of Museums. The Cabinet of Curiosities in sixteenth-and seventeenth-Century Europe. Oxford 1985, p. 132.

8. Pro memoria fra Oeder til Moltke 11. Dec. 1752. i Bregentved Arkiv.

9: Beretning og Forestilling De Kongelige Charlottenborgske Naturalhistoriske Anstalter angaaende. 31. Jan. 1768 i Bregentved Arkiv.

10. Udateret brev fra Morell til Moltke i Bregentved Arkiv.

11. Laverentzen, Johannes: Museum Regium. Hafniae 1710.

12. Aldrovandi, Ulisse: Ornitholgiae hoc est de avibus historiae libri XII, Bologna 1599-1603; De animalibus insectis, Bologna 1602.

13. Hunter, Michael: The cabinet institutionalized: The Royal Society's "Repository» and its background. i Oliver Impey and Arthur McGregor: The Origins of Museums. The Cabinet of
Curiosities in sixteenth- and seventeenth-Century Europe. Oxford 1985, p. 173.

14.Bencard, Mogens: Museerne og Verdensordenen, Kunstkammerets opståen og grundidé. Nordisk Museologi 1993:1, Umeå p. 7.

15. Kaufmann, DaCosta: Remarks on the Collections of Rudolf II: The Kunstkammer as a form of representatio. Art Journal 18. New York 1978, p. 27.

16. Gunnar Broberg giver i sin artikel: En värld av under, Nordisk Museologi 1993:2 p. 19-20 en kort beskrivelse af barokkens opfattelse af ordet.

17. Stroup, Alice: A Company of Scientists. Botany, Patronage and Community at the SeventeenthCentury Parisian Academy of Sciences. Berkeley 1990. p. 223.

18. Thomasius, Christian: Discours, welchergestalt man denen Franzosen im gemeinen Leben und Wandel nachahmen soll. Allgemeine deutsche Bibliographie. Band 38. Leipzig 1894, p. 95.

19. Allgemeine deutsche Bibliographie. Band. 7. Leipzig 1878. p. $219 \mathrm{ff}$.

20. Ole Feldbæk har kort beskrevet den moderne embedsstands opståen i sit afsnit: Stat, forvaltning og samfund i 1700 -tallet. Idealer og realiteter. i Forvaltningshistorisk Antologi. ed. Helle Blomquist og Per Ingesmand. København 1993, p. 91.

21. Gunnar Broberg viser dette i sit i note 16 nævnte arbejde.

* Fremlagt 1. gang under Museumshøjskolens museologiske forelesninger på Nationalmuseet 3. marts 1994

Peter Wagner, cand scient, botanik 1970; museumsinspektor ved Naturvidenskabelig Afdeling på Nationalmuseet 1970-72; fra 1972 ved Botanisk Centralbibliotek. Har publiceret om ved- og barkanatomi, botanikkens historie og lerdomshistorie. Adr: Botanisk Centralbibliotek, Solvgade 83 opgang 5, DK-1307 Kobenhavn K. 